\title{
Unions and the Labor Market for Managers
}

\author{
John DiNardo \\ University of California - Irvine, \\ University of California - Berkeley \\ and \\ NBER \\ Kevin F. Hallock \\ University of Illinois at Urbana-Champaign \\ Jörn-Steffen Pischke * \\ Centre for Economic Performance \\ London School of Economics and NBER
}

August 2000

Keywords: Executives, managers, unions, wage structure, CEOs

JEL Classification: J31, J44, J51

\footnotetext{
* DiNardo: Dept. of Economics, University of California, Irvine, CA on leave at Department of Economics, University of California, Berkeley, CA, 94720, jdinardo@uci.edu. Hallock: Dept. of Economics and Institute of Labor and Industrial Relations, University of Illinois at Urbana-Champaign, Champaign, IL 61820, hallock@uiuc.edu. Pischke: Centre for Economic Performance, London School of Economics London, England, WC2A 2AE, s.pischke@lse.ac.uk. We thank John Abowd, Danny Blanchflower, Barry Hirsch, Kevin Murphy, Joe Tracy and Michael Wallerstein for data, Ben Gordon for excellent research assistance, and Daron Acemoglu, Danny Blanchflower, Donald Deere, Sue Dynarski, Pete Feuille, Wally Hendricks, Barry Hirsch, David Lipsky, David Lewin, and Sendhil Mullainathan. We are grateful to the American Compensation Association for financial support. The views expressed are solely the authors and do not reflect the views or opinions of the American Compensation Association.
} 


\title{
Unions and the Labor Market for Managers
}

\begin{abstract}
We examine the relationship between the employment and compensation of managers and CEOs and the presence of a unionized workforce. We develop a simple effciency wage model, with a tradeoff between higher wages for workers and more monitoring, which requires more managers. The model also assumes rent sharing between workers, managers and the owners of the firm. Unions, by redistributing rents towards the workers, lead to lower employment and lower pay for managers. Using a variety of data sets, we examine the implications of the model for the relationship between the employment and wages of managers and unionization. We find several results generally consistent with our model. (1) Both a higher fraction of unionization in an industry and region and a higher union wage differential are associated with fewer managers. (2) Managers wages are about 5 to 7 percent lower in unionized firms. (3) For CEOs the effects are larger: a 10 percent increase in unionization reduces the pay of CEOs by 2.5 percent or more.
\end{abstract}

Keywords: Executives, managers, unions, wage structure, CEOs

JEL Classification: J31, J44, J51 


\section{Introduction}

Union representation limits management's discretion to set the wages of covered workers and management is required to bargain with the workers' union. The effect of this process on the wages of union workers is clear: unions raise the wages of their members. Abowd (1989) finds that collective bargains are "efficient" (in the sense of maximizing the sum of shareholders' and union members' wealth). Given the evidence that profits are lower in unionized firms (Clark 1984) this suggests that unions redistribute rents from the owners of firms to the workers. If this is the case, it is likely that other constituents in the firm also gain or lose from the presence of unions. In this paper, we look directly at the impact unionization has on employment and compensation of managers.

Bargaining and rent redistribution are likely to be the key mechanisms through which unions impact the employment and pay of managers. At bargaining time and more visibly during periods of industrial disputes, workers often voice concern over the pay and compensation of managers and executives. Anecdotal evidence suggests that when workers are organized, executives or directors feel more pressure to limit the pay of managers. DeAngelo and DeAngelo (1991), for example, find that corporate executives and other white collar workers accepted major pay cuts in years where steel firms sought to obtain pay concessions from blue collar workers in union negotiations.

A large literature in corporate finance tries to analyze the incentives of managers to create and appropriate rents (Jensen and Meckling 1976). This literature has primarily focused on the role of large shareholders, boards of directors, and takeover threats in disciplining management. There is little consideration of how other stakeholders in the firm, like workers, might influence the way the firm is run, and how rents are created and distributed. But in the process of redistributing rents from shareholders and management 
to members, unions affect the behavior of firms in many ways. While there is mixed evidence that unions seem to lower investment and the growth of firms (Blanchflower, Millward and Oswald 1991, Bronars, Deere and Tracy 1994, Machin and Wadhwani 1991) there is some evidence that they raise productivity in some circumstances (Allen 1984, Bronars et al. 1994). This combination of effects may appear counterintuitive at first blush. One explanation has been suggested by Freeman and Medoff (1984) - these effects might be explained by the role of unions as a voice for workers. Another channel, and the possibility we investigate here, is that that unions may directly affect the way firms are managed.

We view the role of managers primarily as supervising and monitoring workers. Because monitoring is imperfect, workers will be paid an efficiency wage. Through bargaining, however, unions redistribute rents towards workers, setting a wage above the level that the firm would have chosen. This makes union jobs more attractive relative to outside alternatives. This, in turn, reduces the need for monitoring, and therefore the firm's need to employ managers. Since the monitoring of workers requires real resources, this process will raise productivity and (static) social welfare, even though unions may impede the investment and growth of unionized firms. This effect has first been discussed by Acemoglu and Newman (1997). The model for the managerial labor market which we present in section 2 builds on their work.

To the best of our knowledge, there is no previous empirical work investigating the link between unionization and executive pay and employment. Our paper tries to fill this gap. To this end we have assembled a variety of different datasets. We begin our empirical investigation in section 3, by analyzing a panel of grouped data by region and industry, which we constructed from the 1983 to 1993 Current Population Surveys for the U.S. These data allow us to examine both the employment and wage effects of unions. In addition, we attempt to tackle the problem that unionization of industries is not chosen randomly, but is likely driven by the presence of rents in a sector. These rents will also be reflected in 
wages, therefore creating a spurious positive correlation between wages of managers and unionization. We use industry wage differentials for non-union workers as a proxy for the rents present in a sector.

In section 4, we use several sources of data on the compensation of U.S. CEOs and unionization at the level of firms. Since the pay of the top executive of publicly held companies has to be disclosed annually, we focus on CEO compensation for the firm level analysis, as does most of the literature on executive pay. Hirsch (1991) and Bronars et al. (1994) have assembled data on the unionization of particular U.S. firms. We use their data together with the pay data for CEOs to investigate the link between unionization and executive pay.

Finally, in section 5 we investigate cross-national data on unionization and the proportion managers in the labor force and CEO pay, both of which differ substantially across countries. We have assembled data on the fraction of managers employed in a variety of countries, which we use in conjunction with a dataset created by Abowd and Bognanno (1995) on CEO compensation. Using all of these different data sources we find the consistent result that unions tend to lower both the employment and the wages of managers and executives. We also find that the presence of rents tends to distort this relationship. Section 6 discusses the results and concludes.

Apart from the theoretical analysis by Acemoglu and Newman (1997), we are not aware that the link between unionization and the managerial labor market has been investigated formally before. Our work is related to three different literatures. First, our paper is linked to the literature on the impact of unions on economic outcomes. Freeman and Medoff (1984) briefly discuss the impact of unions on white collar workers within the same firm (who seem to gain from unionization), but they do not discuss the most highly paid workers: managers and top executives.

Second, our work contributes to the growing literature on CEO compensation. The compensation of top executives varies widely across firms. Although the focus of much 
of the literature has been on the role of firm performance in CEO compensation (Gregg, Machin and Szymanski 1993, Jensen and Murphy 1990), it appears to account for little of the variation in the level of CEO pay across firms. ${ }^{1}$ A related literature has attempted to explain cross-sectional differences in CEO pay. Joskow, Rose and Shepard (1993), for example, ask whether political pressures may limit the level of CEO pay. They find that CEO compensation is lower in regulated industries and that pay is less sensitive to firm performance in these industries. Joskow, Rose and Wolfram (1996) link CEO pay in the electric utility industry even more directly to specific regulatory practices. Akin to regulation, which gives a particular stakeholder group (customers) more voice, unions may be able to affect the pay of CEOs for their own benefit.

Third, there is a link between our investigation and the recent literature on changes in wage inequality. Freeman (1993), Card (1992), and DiNardo, Fortin and Lemieux (1996) have found that the decline in unionization can explain roughly 30 percent of the recent increase in wage inequality in the U.S., while Bell and Pitt (1998) put this number at about 25 percent for the U.K. Moreover, DiNardo and Lemieux (1997) also find an association between the change in unionization and changes in wage inequality comparing the U.S. and Canada. These studies, however, focus only on the unions' wage impacts on covered workers. Since unionized workers typically occupy the lower and middle part of the wage distribution, these papers do not attempt to account for changes in wage inequality that have taken place among non-unionized workers in the top of the wage distribution. If the presence of unions has an impact on the pay of the highly paid as well, however, the decline of unionization in countries like the U.S. and the U.K. might explain an even larger part of the spreading in the wage distributions. This effect would be much more difficult to uncover with these within country accounting exercises. Cross country regressions, as in

\footnotetext{
${ }^{1}$ This is abstracting from the variability introduced by revaluations of stock and option grants as stressed by Hall and Liebman (1998). A survey of the literature can be found in Conyon, Gregg and Machin (1995) and Murphy (1999).
} 
Freeman (1996), on the other hand, should estimate the full effect of unions on the wage distribution.

\section{A Simple Model}

In this section we present a stylized model of the labor market for managers in an economy with unions. The role of managers is to monitor workers. The monitoring technology in the unionized sector is imperfect, so that, in the absence of supervision, workers would not exert enough effort. However, the firm can trade off paying higher wages with hiring more managers, along the lines of the model in Acemoglu and Newman (1997). This implies that unions, by raising the wages of their members, and therefore diminishing the need for supervision, will lower the demand for managers.

Unions also interact with the labor market for managers in a second way. Firms in the unionized sector generate rents which are shared with the employees. It is these rents which attract unions to the sector in the first place. This means that unions are more likely to exist in sectors which pay higher wages, not just to workers but also to managers. On the other hand, unions also redistribute rents from managers to workers. The model therefore does not predict unambiguously whether unions are associated with higher or lower wages for managers.

The model economy consists of two sectors, a unionized sector and a competitive sector. We will take conditions in the competitive sector as given, and concentrate on the wage and employment determination for managers in the unionized sector. Technology in both sectors requires workers to exert effort. However, the sectors differ in that monitoring is perfect in the competitive sector, so that firms can easily enforce no shirking. The monitoring technology in the unionized sector is imperfect. Workers who shirk will be caught with probability $q<1$. Shirkers who are detected lose their job in the unionized sector, but they find employment in the competitive sector at wage $w_{L}^{*}$ during the same 
period. Effort requires a utility cost $e$, so that the no shirking condition in the unionized sector is given by

$$
w_{L}-e \geq(1-q) w_{L}+q\left(w_{L}^{*}-e\right)
$$

Workers who supply effort receive a wage $w_{L}$, but have to pay effort cost $e$. Workers who shirk will not be caught with probability $1-q$, in which case they do not have to pay the effort cost. With probability $q$ they are caught shirking, in which case they are laid off and have to work in the competitive sector at wage $w_{L}^{*}$. Recall that they will have to put forth effort in the competitive sector as well and shirking is not possible in that sector because of perfect monitoring. ${ }^{2}$ Rearranging the expression above yields

$$
w_{L} \geq w_{L}^{*}+\frac{1-q}{q} e
$$

Firms in the unionized sector can choose the monitoring intensity, given by $q$. In particular, we assume that $q=q(m)$ is a function of the number of managers the firm hires per worker, given by $m . q(m)$ is an increasing and concave function. The firm takes wages for managers and workers as given, and maximizes profits

$$
\max _{m, L} \pi=p f(L)-w_{M} m L-w_{L} L
$$

subject to the no shirking constraint in (1), where $L$ is the number of workers, $m L$ is the number of managers hired, and $p$ is the price of the good. Profit maximization implies that (1) always holds as an equality in equlibrium. This is because the firm can always reduce the number of mangers hired for a given worker wage until the constraint is no longer slack, thus reducing costs without changing worker incentives (see Acemoglu and

\footnotetext{
${ }^{2}$ We assume that $w_{L}^{*}-e$ exceeds the workers' reservation utility, so that they will always want to participate in the competitive sector of the economy.
} 
Newman (1997)).

Wages for workers and managers in the unionized sector are determined by bargaining over rents. Rents $R$ generated by a particular firm are

$$
R=p f(L)-w_{M}^{*} m L-w_{L}^{*} L
$$

where $w_{i}^{*}$ denotes the competitive wage for group $i$. The firm cares about profits, while workers and managers care about the surplus they receive compared to working elsewhere

$$
\begin{aligned}
S_{M} & =\left(w_{M}-w_{M}^{*}\right) m L \\
S_{L} & =\left(w_{L}-w_{L}^{*}\right) L
\end{aligned}
$$

where $S_{i}$ is the surplus. Three-way Nash bargaining maximizes

$$
S_{M}^{a} S_{L}^{b} \pi^{1-a-b}
$$

and $a$ and $b$ are the bargaining parameters of managers and workers, respectively. We assume that these bargaining parameters depend on the degree of unionization, with $a^{\prime}(U)<0$ and $b^{\prime}(U)>0$. This leads to the wage rules ${ }^{3}$

$$
\begin{aligned}
w_{M} & =w_{M}^{*}+a(U) \frac{R}{m L} \\
w_{L} & =w_{L}^{*}+b(U) \frac{R}{L} .
\end{aligned}
$$

Employment and wages for managers in the unionized sector are now easy to determine. (1) written as an equality determines employment for managers. Define $Q(m) \equiv(1-$

\footnotetext{
${ }^{3}$ In principle, firms may want to set a higher wage for workers than the bargained wage if the bargained wage was below the profit maximizing efficiency wage. In practice, this will not occur, because unions will realize this and push the wage for workers up even further. Therefore, this constraint is implicitly taken into account in the bargaining parameters $a$ and $b$.
} 
$q(m)) / q(m) . Q$ is a strictly decreasing function. It can therefore be inverted to yield

$$
\begin{aligned}
m & =Q^{-1}\left(\frac{w_{L}-w_{L}^{*}}{e}\right) \\
& =Q^{-1}\left(\frac{b(U) R / L}{e}\right)
\end{aligned}
$$

using the wage equation (3) for workers. Higher rents and more unionization are associated with fewer managers per worker. This is because rents and unions raise the wage differential for workers, make shirking less attractive, and therefore reduce the need for direct monitoring.

Equation (4) also makes clear, that in a unionized firm it is only the union wage differential $w_{L}-w_{L}^{*}$ that should matter for the fraction of managers hired. We can control for the union wage differential at the industry level directly in our empirical estimates. However, note that the interpretation of equation (4) at the industry level will differ if there are both union and non-union firms in the industry. The fraction of managers hired in union firms will generally be lower than in non-union firms. It will also be lower in unionized firms the higher the union wage differential. This illustrates that the fraction of managers at the industry level still depends on both the union wage differential and the unionization rate.

Unions only affect managers in the model because they raise wages for workers. It is well known, however, that unions also change other aspects of the employment relationship. One is layoff rules. The fact that it is more difficult to fire union workers may imply that the layoff probability $q$ is directly a function of the unionization rate, i.e. $q(m, U)$ with $\partial q / \partial U<0$. Through this channel, unions will make shirking more attractive, because the penalty of a layoff is less likely. This means that the firm will have to hire more managers, in order to raise the probability of detection, but also to document worker misbehavior more carefully, pursue grievances, etc. In this expanded version of the model, the net effect on 
managerial employment is ambiguous, since higher wages still deter shirking. Therefore, which channel is more important is an empirical question. Since we find large negative effects of unions on managerial employment below, we conclude that the effect of unions on wages is the more important ingredient of the model.

However, is also possible that rent-sharing alone determines both wages and employment for managers. In this view, more rents will be used by managers for empire builing. This implies hiring more subordinates, i.e. lower level managers, thus creating an unnecessarily large and bloated organization. In this case, higher rents are associated with more managers not fewer, as in equation (4). Most of our results do not speak to the distinction between these two views directly, since we investigate the effect of unionization rather than rents on the level of employment of managers. However, some of our results in Table II below are consistent with the rent-sharing view of mangerial employment.

Wages for managers are given by (3), which implies that more unionization leads to lower wages for managers, because unions are able to redistribute rents from the firm's owners and from managers towards workers. However, note that this relationship only holds for a given level of rents. In order to close the model we need to discuss how unionization in an industry is determined. The degree of unionization should depend on the benefits and costs of unionization. Ceteris paribus, unions will tend to organize industries with higher rents. However, costs of organizing different industries will differ. For example, manufacturing firms with few large plants may be easier to organize than service firms with many small establishments. Industries will also differ in how easy it is to raise wages in the industry, implictly given by the shape of $b(U)$ in our model. This can be summarized as

$$
U=U(R, \text { state and industry characteristics })
$$

It is clear from this discussion that the wages of managers may be positively associated 
with the degree of unionization if rents are not adequately controlled for. One way to control for this problem empirically would be to use state and industry characteristics to instrument for unionization rates. However, it is difficult to find observables that are powerful enough to predict unionization rates, especially variation within regions and industries over time. We therefore concentrate on proxying rents directly. In particular, we use the industry wage differential for non-union workers as a control. The rationale for this is the evidence that industry wage differentials are likely due to rent sharing, and that these rents are shared with all workers, not just union workers (see Katz and Summers (1989), and Dickens and Katz (1987)). ${ }^{4}$ One complication with this strategy is that unions may affect the rents earned by a firm directly. In this case, it would be difficult to interpret the coeffcient on the unionization variable controlling for rents (see Angrist and Krueger (1999)). However, since rents are difficult to measure there is no empirical evidence that workers influence rents directly. In addition, controlling for rents is the best strategy we have available for estimating the causal effect of unionization on the pay and employment of managers.

Our discussion of the factors driving unionization in an industry highlights that we are relying on cost factors to identify the unionization variable. This implies that it should be more difficult to identify the effects of unionization and rents separately if we try to control for industry effects directly, thus purging the unionization variable of much of its identifying variation.

How can we use this model to think about the compensation of CEOs? Clearly, we can apply the wage equation (3) in a similar way as for lower level managers. On the other hand, there is one CEO per firm, so there is no natural quantity measure reflecting the intensity of CEO use. We assume that firms or industries which use managers more intensively (i.e. have a higher fraction of managers), will need a more skilled CEO. We

\footnotetext{
${ }^{4}$ Note that this is not really inconsistent with the model above. Wages in the "competitive" (non-union) sector $w_{L}^{*}$ may also reflect rents.
} 
therefore expect higher pay for CEOs wherever we see more managers employed. Since unions should depress the employment of managers we expect to be more likely to find a negative corrrelation between unions and the pay for CEOs as compared to the pay for lower level managers.

\section{Industry Level Results for U.S. Managers}

While the theoretical analysis suggests that we examine the concentration of managers in unionized versus non-unionized firms, data on the fraction of managers are not as readily available at the firm level. However, the implications of the theory can also be investigated with data at the industry level. Hence, we follow the strategy of Neumark and Wachter (1995), and analyze the pay of managers at the level of industry and regional cells, which we construct from the Current Population Survey (CPS). Neumark and Wachter use industry level data from the CPS for the period 1973 to 1989 and find that a 10 point higher fraction of blue collar workers unionized in an industry is associated with 1.8 percent lower wages for managers and professionals.

We use the 1983 to 1993 Merged Outgoing Rotation Groups from the CPS to construct cells at the industry/region/year level. Our sample starts in 1983 because this is the first year where union status is available for the outgoing rotation groups. In order to have cells of sufficient size, we aggregated two digit industries into 26 broader industries, and states into 16 regions. A complete list of the industry and state cells used is given in Appendix 1. The key occupation group we are interested in is executives and managers (1980 3-digit SIC occupation codes 3-22). These are primarily occupations who supervise others. In

principle, workers in this group cannot form unions under NLRB rules. However, the line between this group of managers and management related occupations and business specialists like accountants, analysts, inspectors, etc. is often not very clear. We therefore also present results on this second group (occupation codes 23-37). We refer to the occu- 
pations in SIC codes 203-889 as workers. This includes all occupations except managerial and professional occupations. We split the group of workers into those who are covered by collective bargaining themselves, and non-union workers. Our samples are restricted to those working five or more hours, who are in the private sector and not self-employed, and with valid wage and occupation information in the CPS.

Table I provides means of the characteristics of these four groups (managers, management related occupations, non-union and union workers) for the years 1983 and 1993. Managers and union workers tend to be older (and have more potential experience) than the other groups. For each of these groups we report two measures of unionization. The fraction unionized in the occupation refers to the fraction of observations in this occupation who respond that they are covered by a union contract. Between 5 and 6 percent of managers and related occupations in 1983 report that they are covered by collective bargaining. This is surprising since we do not expect managers to be organized in unions. This result may be due to measurement error because either the union or the occupation question are answered or coded incorrectly. However, 5 percent seems a little too high as compared with typical misclassification rates (Card 1996) so that some of this may reflect actual unionization of this group. Some managers may be in relatively low level positions, who do not directly supervise others, and who are therefore not subject to NLRB rules. When we run standard cross-sectional wage regressions, we find that unionized managers have roughly 8 percent higher wages than other managers, about half the union wage differential typically found for all workers. This also seems to indicate that at least some of this may reflect actual unionization of the group.

The penultimate row in each panel in Table I reports the fraction of unionized workers (those who are neither managers, related, or professionals) in the industry/region cells to which a manager or worker belongs. If all occupations were equally distributed across these cells, this number would be constant across the different columns (except for sampling variation) and would reflect the unionization level of workers in the economy. But different 
occupations tend to be more concentrated in certain industries. For example, there are more managers in banking and other finance than there are in the construction industry. Since the unionization rates of workers in these industries differ, and since the reported means for managers, say, are weighted by the number of managers in a cell, the fraction of union workers reported for each occupation differs. Thus, the fraction of union workers refers to the exposure of the occupation to unionized workers in the particular cell. The most notable, but unsurprising result about this fraction is that union workers tend to be concentrated in industry/region cells which are more highly unionized. Exposure to unionized workers has declined for all occupations over time. The last row in each panel reports the fraction of managers in the industry/region cell to which an occupation belongs. This fraction differs little by occupation. For each occupation there is about a 1.5 or 2 percentage point increase in the fraction of managers over the sample period.

In order to assess the effect of unions on the pay of managers, we estimate a regression of the form

$$
\ln w_{i j t}^{s}=X_{i j t}^{s} \beta+\gamma u_{j t}^{s}+\mu_{j}+\eta^{s}+\delta_{t}+\varepsilon_{i j t}^{s}
$$

$w_{i j t}^{s}$ is the wage of individual $i$ in industry $j$ and state $s$ at time $t . X_{i j t}^{s}$ is a set of covariates which includes years of schooling, potential experience and its square, and dummies for female, black, whether the individual lives in an SMSA, and part-time status (less than 35 hours a week). $u_{j t}^{s}$ is the fraction of workers who are unionized in each state/industry/time cell. Notice that this variable does not vary at the individual level. In order to implement the estimation of this model and to obtain standard errors robust to a group structure in $\varepsilon_{i j t}^{s}$ we first regressed $\ln w_{i j t}^{s}$ on $X_{i j t}^{s}$ and a full set of industry/state/year interactions. In a second stage, we regressed the coefficients from these dummy variables on the fraction of workers unionized in the industry. The second stage regression is weighted by the number of observations in the cell. The results from the second stage regression are shown in 
Table III (see below). In order to examine the effect of unions on the employment of managers, we pooled the observations for all occupations in a state/industry/year cell, calculated the fraction of managers in the cell, and regressed it on the fraction of unionized workers.

Table II displays results of the employment regressions in two panels for the dependent variables, fraction managers and fraction managers and related occupations. In the first column of the top panel we display estimates from a regression of the fraction of managers in the cell on the fraction of workers unionized. This and all the following regressions also control for separate industry, region, and year effects. These effects are necessary to account for the different employment structures of various industries and regional differences. The effect of unionization on the employment of managers is strongly negative and significant. A 10 percentage point increase in the unionization rate leads to about 0.8 percentage points fewer managers. This is a sizeable effect given that the average fraction of managers in the sample is about 9 percent. It implies that the fall in unionization can account for about 25 percent of the increase in the fraction managers hired during the sample period.

The discussion in the previous section showed that unions affect the employment of managers through the union wage differential. In column (2), we add this variable to the regression. As predicted, the union wage differential has a significant negative impact on the fraction managers. The magnitude of the union wage differential is somewhat smaller than the impact of the incidence of unionization. A 15 percent differential accounts for about 0.6 percent fewer managers. Also notice that the inclusion of the union wage differential only attenuates the coefficient on the fraction of workers unionized slightly. This is as expected. Since the majority of workers are not covered by collective bargaining, extending coverage at a constant wage differential should have a substantial effect.

One potential problem with our estimates is that unionization may not change completely randomly within an industry-region cell, and this could influence our estimates. We 
believe that both the presence of rents and industry and region characteristics will drive the degree of unionization. In order to probe whether this is the case, and whether our results are robust to different specifications, we add two different variables to the regression. The first is industry*year interactions. This variable should eliminate some of the cost factors associated with the level of unionization, which are useful in identifying the desirable effects. Alternatively, including the industry wage differential should eliminate some or all of the effect in unionization due to rents. In our model, the employment of managers is rationed by the firm, so that rents should not play a large role for the fraction of managers, i.e. the results should be fairly robust to these modifications.

Column (3) displays the results adding industry* year interactions. Both the coefficient on the fraction of workers unionized and on the union wage differential are reduced in magnitude, but remain negative and significant. This seems to indicate that rents do influence the employment levels of managers somewhat. The final three columns repeat the previous specifications including the industry wage differential as a regressor. This raises the coefficient on the fraction of workers unionized slightly (in absolute value) but has the opposite effect on the coefficient on the union wage differential. However, these impacts are comparatively minor. Overall, the results are very consistent and in accord with the theoretical expectations. The only exception is rents, as proxied by the industry wage differential, which are positively associated with the employment of managers, contrary to the predicitons of our model. One explanation for this finding may be that firms with more rents can afford more bloated organizations.

The second panel in Table II combines managers and management related occupations and uses the fraction of both as the dependent variable. All the qualitative results are similar to what we found for the narrower group of managers only. However, the magnitudes of the coefficients are now larger, which makes sense since the impacted group is broader. Furthermore, rents seem to play more of a role for this broader group as the results change more when we include industry* year effects and the industry wage differential as controls. 
Next we turn to the effects on wages still using our CPS data. Table III displays the results, which are organized in a way similar to the previous table. All regressions again control for industry, region, and year effects. One difference from the previous table is that the lower panel now refers only to management related occupations and does not pool them with managers. The results in column (1) indicate a small positive but insignificant association between the unionization of workers and the wages of managers (upper panel) and a negative and marginally significant association for management related occupations (lower panel). Since we have seen that some managers report being covered by collective bargaining themselves, we also include the unionization rate of managers or related occupations in column (2). This turns out to be unimportant as the results for the unionization rate of the workers are unchanged.

The relatively weak association between unionization of workers and wages of managers is not unexpected based on our theoretical discussion, since more unionization will both lead to lower pay of managers and proxy for higher rents, which are associated with higher pay. These suspicions are borne out in the remaining columns of the table. When we include industry*year effects, as in column (3), thereby eliminating some of the variation in costs of unionization, we find a much more strongly positive association of the unionization rate with wages of managers. We interpret this as showing that much of the remaining variation in the fraction of workers unionized comes from rents, which is positively related to managerial pay. Column (4) does the opposite experiment and controls for rents using the industry wage differential. This now leads to a negative and significant coefficient both for managers and related occupations. Furthermore, the coefficent on the industry wage differential is positive and large, reflecting the fact that industry wage differentials correlate strongly across occupations (see Katz and Summers (1989)). When we include both industry*year effects and industry wage differentials (column 6) any effect of the unionization of workers on the pay of managers is small now, reflecting a combination of the results in columns (3) and (5). 
Hence, the results indicate that the presence of rents is an important confounding factor in the estimation of the effects of unionization on the compensation of managers. Columns (4) and (5) are our best attempts to purge this variation from the regression, so that the estimates we find there should reflect the effect of higher unionization on the wages of managers. According to equation (3), this is the slope of the bargaining parameter of the managers $a(U)$, and therefore reflects redistribution from managers to workers. The pay of managers or related occupations is reduced by about 5 to 7 percent in an industry that is completely unionized compared to one that is non-union. This indicates that unions seem to have substantial power to redistribute rents from managers to workers.

Our results for wages are comparable to the findings of Neumark and Wachter (1995), which is similar in spirit to our study although they consider a different time period. Using industry level data, they find that higher unionization of workers is associated with lower pay for non-union workers and managers, controlling for main industry and year effects. On the other hand, when they use city level data, they find the opposite effect on nonunion workers. As we stressed in our theoretical analysis, their results, as ours, are likely to reflect the impact of both unionization and rents. Our results combine both of the sources of variation used by Neumark and Wachter (1995) and we have demonstrated that it is easily possible to get either positive or negative effects, depending on the identifying source of variation in the unionization variable. Their specification is closest to column (2) in our table III, where we do not control for industry wage differentials and do not find unambiguously negative effects. ${ }^{5}$

\section{The Unionization of U.S. Firms and CEO Pay}

To complement our analysis using industry level data, we also examine the same issues using firm level data. There are two basic data problems in considering firms. The first

\footnotetext{
${ }^{5} \mathrm{~A}$ further difference is that they also include professionals in the group of managers.
} 
problem is that data on the fraction of managers within a firm and the pay level of managers is not available. We therefore concentrate on the pay of the highest level manager in the firm: the CEO. CEOs may also share in the rents generated by the firm, so CEO pay should be higher in a firm where the pay of other managers is higher. Furthermore, we would expect that CEOs in firms with many managers get paid more. One reason is that supervision in a more complex organization will be more difficult. In addition, a firm with more managers will have more levels of hierarchy and we expect pay to rise. Therefore, CEO pay is a useful variable to examine. In addition, the effect of more unionization on CEO pay should be the same regardless of the channel: CEO pay will be lower because unions redistribute rents away from managers and it will be lower because unionized firms require fewer managers and therefore allow a leaner organizational structure. We therefore expect a stronger relationship between unionization and CEO pay than with the pay of lower level mangagers. On the other hand, it will be more difficult to account properly for rents in the firm level regressions, so that the direct effect of unionization will also be muted. While we would like to have data on other managers at the firm level, the effects of unions on CEOs are also interesting in their own right.

The second problem is that data on the unionization of individual firms are not readily available. Nevertheless, it is possible to gather these data through a variety of channels. Bronars et al. (1994) constructed unionization measures for a sample of large U.S. firms from the Bureau of Labor Statistics Bargaining Calendar. The Bargaining Calendar contains information on the workers covered by collective bargaining agreements in particular establishments. By dividing this information on the number of covered workers by employment from Compustat, the authors were able to construct coverage rates for individual firms. One shortcoming of this exercise is that the sample is limited to firms which had any collective bargaining agreements, i.e. a unionization rate greater than zero. This is simply because matching the universe of contracts to the universe of firms is virtually impossible. The sample is also limited to firms with contracts covering at least 1000 work- 
ers. Because the union employment data have to be interpolated between contract dates, Bronars, Deere, and Tracy constructed four year averages of their unionization measures to lessen the impact of this smoothing. Their data cover the periods 1971-1974, 1975-1978, and 1979-1982.

A different approach was pursued by Hirsch (1991), who conducted a survey of large U.S. employers in manufacturing about their unionization rates in 1987. The survey contained questions on the current unionization level and retrospective questions about unionization in 1977. The Hirsch data refer to the firm's entire workforce in the U.S. and Canada. Neither data source has information on the union wage differential. We obtained both the Bronars, Deere, and Tracy data and the Hirsch data for 1977. For the analysis below, we merged both datasets with information about the firms from Compustat and with CEO pay data from the United States which are published annually in Forbes magazine. We obtained the latter data for the relevant sample years from Kevin Murphy.

In Table IV we run OLS regressions of CEO pay on the Bronars, Deere, and Tracy measure of unionization and a variety of other covariates. Our measure of CEO pay is the logarithm of salary, bonuses, and the value of other compensation but excluding the value of stock or option grants. The latter part of compensation is potentially large for many CEOs but the U.S. Securities and Exchange Commission has only recently required firms to uniformly disclose options in a given year. Forbes does report the value of exercised options in a given year which some authors add to salary, bonus, and other compensation to arrive at total compensation. However, this is not really a good measure of total compensation because the value of options should be included in compensation when they are received, not when they are exercised. If we additionally include the value of exercised options in compensation in this section we get very similar results (which are not reported in the tables). Furthermore, although stock options are currently a large fraction of compensation, they were not as important during our sample period.

The specifications include regressors which are typically found in cross-sectional regres- 
sions for the level of CEO compensation: the years of age and tenure of the CEO and the square of these variables, the logarithm of sales and employment to control for firm size effects, and the change in the value of the firm (return) during the four year period and its lag. Except for the change in the value of the firm (return), these regressors are constructed as the average over the four year period (before taking logs or squares). Since CEOs may turn over during any four year interval we also control for whether the CEO changes during the period. Finally, we control for period effects to capture aggregate growth in CEO pay, and the impact of changing market returns for these firms, etc.

Our key regressor is the fraction of employees covered by union contracts in the firm. In table IV, we find that CEO pay is lower by about 3 percent for a 10 percentage point increase in unionization (in column 1). This is consistent with the model but the effects are larger than what we found in the industry level equations for all managers. In that case, using the best available control for rents, we found 0.5 to 0.7 percent lower wages for a ten percentage point increase in unionization, and an effect of a similar magnitude on the fraction of managers. While we believe that the effect on CEOs should combine both a direct wage effect and another effect due to the impact of unions on organizational structure, unions seem to have a much larger impact on the pay of CEOs than they do on the pay of lower level managers. This could be because a much larger fraction of CEO pay is due to rents, rather than reflecting just outside options, as compared to lower level managers. ${ }^{6}$ Of course, the presence of rents, which are very likely correlated with unionization rates, also means that the causal effect of unions on CEO pay should be even more extreme.

For comparability with the Hirsch data (below) we also ran these regressions separately for manufacturing and non-manufacturing industries. Results are displayed in columns (2)

\footnotetext{
${ }^{6}$ This is consistent with the Crystal (1992) view of CEO compensation. See Bertrand and Mullainathan (2000) for some evidence that CEO pay is rather sensitive to shocks which change the level of rents earned by a firm.
} 
and (3). The relationship between CEO pay and unionization is weaker within sectors, a 10 percentage point increase in unionization means only about a 1.9 percent lower executive pay. In columns (4) to (6) we go one step further and exploit the panel nature of the dataset. While we are unable to find satisfactory controls for rents, we can control for industry (in columns (4) and (5)) or firm effects (column (6)). We expect that much of the across industry variation is related to the cost of unionizing a firm, so that the bias due to rents should become more pronounced once we include industry or firm effects. ${ }^{7}$ This is indeed borne out in the data. Including 44 two digit industry effects leads to an effect of -0.12, and this effect goes to zero once 103 three digit industry effects are included. An even more extreme result is found when we control for firm effects: in this case there is a positive and significant association between unionization rates and CEO pay. A 10 percentage point increase in unionization means 2.5 percent higher executive pay. ${ }^{8}$

Table V presents our results using the Hirsch data. The regressions are specified analogously to the previous tables but the sample is a simple cross section. For comparability across data sets, and because there is large variability in CEO pay from year to year, we used the same four year aggregates of the variables for these regressions as well. Thus, all variables refer to the period 1975-1978, except for the unionization measure, which refers to the period 1977. However, recall that this is a retrospective survey measure (taken in 1987), so that the respondent may well have reported something closer to an average for the years roughly ten years ago. When we run these regressions with data only for 1977

\footnotetext{
${ }^{7}$ Notice that we contrast regressions with and without controls for industry effects here, while we contrasted regressions with and without industry*year interactions, but always controlling for industry main effects in the analysis of the industry-region data above. Controlling for industry main effects in the earlier regressions was necessary, since the group of "managers" is rather heterogeneous across industries, and this heterogeneity is reflected in wages. The CEOs of large enterprises, which are the focus of our analysis in the firm level regressions, are a much more homogeneous group by comparison. Differences in CEO pay across these industries is therefore much more likely related to unionization and rents, rather than to unobserved differences across CEOs.

${ }^{8}$ The positive effect is entirely due to the changes from the 1975-1978 to the 1979-1982 period. However, we do not have a satisfactory explanation for the differences between that period and the rest of the sample period.
} 
we find basically the same results.

A 10 percentage point increase in the unionization rate in the Hirsch data is associated with 1.5 percent lower executive pay. This effect is somewhat smaller than our basic finding in the Bronars, Deere and Tracy data. Recall that the former only includes firms with positive unionization. The effect is slightly larger when we impose the same sample restriction in the Hirsch data. In fact, the resulting coefficient in column (2) is -0.19, virtually identical with the finding in the Bronars, Deere, and Tracy data for manufacturing only (Table IV, column 2). The results in the Hirsch data are slightly less precise, because this dataset is rather small.

As before, regressions including two and three digit industry dummies lead to less negative estimates of the relationship between CEO pay and unionization. These are displayed in columns (3) and (4). Unlike in the Bronars, Deere, and Tracy data, the relationship is not quite monotonic now: the coefficient actually becomes slightly more negative when we go from two digit to three digit industry controls. However, in neither case is the coefficient on fraction unionized significantly different from zero. We obviously cannot include firm effects as in Table IV since this is a simple cross section.

Another issue in all of these regressions is that the measures of unionization are rather imperfect, so that our coefficients are also likely to be biased because of measurement error. Because the Hirsch measure and the Bronars, Deere, and Tracy data are constructed independently, it seems sensible to assume that the errors in these measures might be independent. Bronars, Deere, and Tracy analyze the correlation between the two measures in the subsample of the data for the same firms. Under the assumption of classical measurement error, they conclude that the relevant attenuation factors for both their data and the Hirsch data are about 0.55. Furthermore, the same applies when they isolate within industry variation in the data. This means that the coefficients should be roughly multiplied by 2 to eliminate the attenuation bias from measurement error. We found roughly similar changes in the coefficients using IV estimates on the overlapping sample, indicating that 
these conclusions are unchanged partialling out the effects of our covariates. Additional attenuation due to measurement error is therefore unlikely a good explanation of our findings when we control for industry or firm effects. Attenuation does not seem to be much greater within industries, while we find that the union coefficient is substantially closer to zero in the within industry regressions. This effect is therefore likely due to rents.

\section{International Comparisons}

Many observers have noted that American CEOs tend to be paid much more than CEOs in other countries, whether in terms of direct comparisons or relative to other workers in the economy (see for example Crystal (1992), and Bok (1993)). In addition, Acemoglu and Newman (1997) note that the proportion of managers in the workforce is much higher in the U.S. and Canada compared to European economies. Both of these facts are predicted by our theory, since unionization is lower in the U.S. and Canada compared to Europe. In this section, we use data from a variety of countries to investigate these relationships more formally.

In order to examine the concentration of managers, we have calculated the fraction managers using data on employment by occupation from the ILO Yearbook of Labor Statistics. Details on the data and the construction of the sample can be found in Appendix 2. We obtained data on union membership from the Trade Union Membership Database by Visser (1997). We used what Visser refers to as net union membership (excluding retired and self-employed union members), and imputed net membership from gross membership where only the latter was available. Both the fraction managers and the unionization rate is available for various years for Austria, Canada, Denmark, Finland, Greece, Ireland, Japan, the Netherlands, New Zealand, Norway, Spain, Sweden Switzerland, Turkey, the U.K., and the U.S. The sample covers the period from 1970 to 1993, but it is a highly unbalanced panel with 189 observations. 
Union membership rates may not be the most appropriate variable for this exercise. What matters for the wages of most workers in many countries are coverage rates, not membership, so our theory suggests that coverage would be the more appropriate variable. Freeman (1996) finds that coverage rates across countries are more strongly associated with wage inequality than unionization rates. Unfortunately, coverage rates are extremely difficult to construct and not as readily available. The OECD (1994) and OECD (1997) include published data for union coverage for the years 1980, 1985, 1990, and the early to mid 1990s for a number of countries. We use these data to complement the results on unionization rates. Since the coverage sample is relatively small, we interpolated the coverage numbers to adjacent years where this resulted in additional overlaps with the years for which we observe the fraction of managers. Since coverage rates hardly move for most countries, there should be little error introduced by this. The coverage sample includes the countries Austria, Canada, Denmark, Finland, Japan, the Netherlands, New Zealand, Norway, Spain, Switzerland, and the U.S. Since coverage rates are only available for a few years, this sample only has 28 observations, spanning the years 1980 to 1995 .

The percentage managers varies widely across countries, from below 2 percent in Spain, Greece, and Turkey, to a high of 15 percent in the U.K.. In most countries this fraction is rather stable over time, but it has grown from about 10 percent in 1970 to 13 percent in 1993 in the U.S., and from 6 percent in 1973 to 13 percent in 1993 in Canada. Table VI displays the results of regressions of the fraction managers on union membership or coverage rates. Column (1) shows OLS results for the pooled samples. The coefficent is -0.05 using the membership data and -0.09 using the coverage rates, and the latter coefficent is significant. The cross-sectional relationship between coverage rates and the fraction managers is closer because membership and coverage can diverge significantly in some countries. Spain, for example, had a unionization rate of about 16 percent in 1990, but 76 percent of the workforce where covered by collective bargaining agreements. Since Spain and other countries like it have very few managers, the relationship with coverage 
rates fits more closely.

Introducing time dummies into the regresssions in column (2) changes the results little. However, we cannot recover the same negative relationship once we control for country effects. This largely stems from the fact that there are few countries with much variation in unionization rates. The results on union membership rates are largely driven by two countries, the U.S. and Canada. For both countries we have long time series of the dependent variable and the regressor. In the U.S., unionization rates have fallen while the percentage managers has increased. Canadian unionization rates are flat or have risen slightly, while the percentage managers increased very rapidly. This drives the positive point estimate. Excluding Canada (in column 4) we find no relationship between the fraction managers and union membership. Unfortunately, we do not have a long time series for the other countries where unionization changed significantly, the U.K. and New Zealand. It is obvious from the large standard errors in the coverage regressions that the within country relationship is rather poorly determined.

Next, in table VII, we turn again to the pay of managers. Abowd and Bognanno (1995) have assembled comparable data on CEO pay from a variety of compensation consulting firms for 12 OECD countries for the most comprehensive international comparison. They document that CEO pay is highest in the U.S. In addition, they try to explain international compensation patterns with the structure of taxation. While they find no impact of corporate taxes, personal marginal tax rates seem to have a large impact on the level of CEO compensation. Nevertheless, a significant U.S. residual remains unexplained.

We have obtained the compensation data used by Abowd and Bognanno (1995). We will briefly describe the main features of the dataset, the details of which are documented in the appendix to their paper. The data are for 1984 and annually from 1988 to 1992, and cover the countries Belgium, Canada, France, Germany, Italy, Japan, the Netherlands, Spain, Sweden, Switzerland, the U.K., and the U.S. They are based on reports by various compensation consulting firms; and in some instances data from more than one source are 
available for a single year. Abowd and Bognanno (1995) collected data for a variety of high level managers. For the sake of brevity, we only report results for CEOs. ${ }^{9}$

The compensation amounts refer to total compensation, including cash compensation, benefits and perquisites, and long term compensation in the form of stock or option grants. Abowd and Bognanno (1995) refer to this as the total compensation cost, the amount a firm has to spend on an executive. An important question is how to make these costs comparable across countries. We use two approaches. The first is a real measure of compensation at actual exchange rates by converting compensation into U.S. dollars for each year and deflating by the U.S. consumer price index. Comparisons using the real measure will reflect the strong depreciation of the dollar over the sample period. This is avoided by using OECD purchasing power parity exchange rates and the OECD index of consumer prices. However, there is necessarily a degree of arbitrariness in PPP exchange rates. $^{10}$

Table VII contain the regression results. As in the previous table, the top panel includes the union membership rate while the bottom panel displays regressions using the coverage rate. We start in column (1) of the top panel by presenting results including the country's unionization rate, time dummies, and dummies for source of the compensation data. Unionization is associated with 50 log points lower CEO pay in the first column. Column (2) includes a dummy variable for the U.S. and a U.S. specific time trend. It reveals that about half of the previous union effect is due to the presence of the U.S. in the dataset. Executive pay is about $80 \log$ points higher in the U.S. than in Europe and Japan, with the gap shrinking slowly. If we do not control for unionization, the U.S. dummy is about 0.88 , only slightly higher, so that unionization alone does not explain the high level

\footnotetext{
${ }^{9}$ We obtained similar results when we repeated the same exercise using human resources managers (see DiNardo, Hallock and Pischke (1997)).

${ }^{10} \mathrm{~A}$ third method involves the contrast between executives and a comparison group within the same country. We find roughly similar results comparing executives to non-supervisory manufacturing workers, although the magnitudes are greater since unions affect not only the pay of executives but the pay of workers as well. See DiNardo et al. (1997).
} 
of CEO pay in the U.S.

In the next column, we run a specification similar to Abowd and Bognanno (1995). These regressions include a time trend (instead of time dummies), a U.S. dummy, a U.S. trend, the marginal employee tax rate including both income and payroll taxes, the marginal corporate tax rate, and dummy variables for the data source. ${ }^{11}$ Changing the specification in this way does relatively little to the union coefficient although the marginal employee tax rate and the unionization rates have a correlation of about 0.5 in this sample. The fourth column presents results controlling for country fixed effects. Unfortunately, there is even less within country variation in unionization in this sample spanning less than a decade. The right hand panel in Table VI presents results using the PPP measure instead of the real measure of compensation. The effects on the unionization rate become stronger in the cross-sectional regressions now, but the qualitative results are little changed.

The lower panel repeats these results on a smaller sample using coverage rates instead of unionization rates. The results are largely similar to those obtained with the membership rates, although the point estimates tend to be somewhat closer to zero. The U.S. seems to be primarily responsible for the negative cross-sectional relationship in this sample, because it is the only country with a substantially different coverage rate from the rest of the countries. The within country relationship is still negative, on the other hand, but the estimates are also imprecise.

Overall, we find a large negative association between unionization rates and the fraction managers and executive pay in a cross section of countries. Going from no unionization to 100 percent unionization typically implies about 5 to 10 percentage points fewer managers and 40 to 60 percent lower compensation for CEOs. However, these effects are mostly due to between country differences and are not mirrored by similar associations between changes in the fraction managers or pay growth and changes in unionization rates within our sample

\footnotetext{
${ }^{11}$ Unlike Abowd and Bognanno, we do not control for the average size of a company in our regressions, so that our results are not exactly comparable and differ slightly.
} 
countries because of a lack of within country variation in unionization. Nevertheless, these results in conjunction with our earlier findings for industries and firms in the U.S. are rather consistent with a significant effect of unions on the mangerial labor market.

\section{Discussion and Conclusion}

The empirical results we have presented paint a picture of the influence of unions on the managerial labor market, which closely matches the predictions of our model. It is well known that unions raise the wages of their members. This reduces the need for explicit monitoring, because it relaxes the no-shirking constraint. This result is borne out strongly in the CPS data we have analyzed but also holds across countries. Both a higher fraction of unionization in an industry and region and a higher union wage differential are associated with fewer managers. A 10 percentage point increase in unionization lowers the fraction of managers by 0.7 to 0.9 percentage points. The effect is about twice as large when we broaden the measure of managers to include related occupations. On top of this, a 15 percent union wage differential accounts for another 0.6 percentage point reduction in the fraction managers.

According to our model, the employment results for managers are the effect of unions redistributing rents from managers to workers. We also find support for this idea in the data, but it is more easily obscured by the amount of rents available in a firm or industry. In the industry level data, where we are able to proxy for rents with industry wage differentials, we find consistently lower wages of about 0.5 to 0.7 percent for managers as well as for related occupations in response to a 10 percent increase in unionization. For CEOs the effects are much larger: the same increase in unionization reduces the pay of CEOs on the order of 2.5 percent or more. This is true across firms in the U.S. as well as across countries. We believe that this difference is likely to be real. The reason is that unions affect CEOs both because they lead to a leaner organizational structure with fewer 
managers and because rents play a larger role in the pay of CEOs than in the pay of managers. The literature on CEO compensation has long conjectured that CEOs are cream skimming in companies that earn rents and that the potential to so may be substantial (See e.g. Crystal (1992) and Hallock (1997)). A recent piece of evidence is Bertrand and Mullainathan (2000), which investigates whether CEOs are rewarded for firm perfomance that is purely due to luck. They find that CEO compensation has a substantial elasticity with respect to such lucky shocks, in the same order of magnitude as the elasticity to the entire variance in firm performance. This indicates that the ability of CEOs to cream skim should be substantial in most companies. Bertrand and Mullainathan (2000) find that shareholder concentration and smaller boards limit the amount of cream skimming. Our results indicate that unions may play a similar role in policing CEO pay. It would be interesting to test this notion more directly by applying their methodology to union and non-union firms, something that is beyond the scope of this paper. In addition, our results of unions on CEO pay mirror the effects found by Joskow et al. (1993) on the effects of regulation. Their empirical results are stronger, presumably because there is ample variation in regulatory regimes within industries induced by changes in the political climate during the past decades. They also interpret their results as redistribtion of rents across the stakeholder groups of an enterprise.

While our results already confirm that rents must be a substantial part of CEO pay in non-union firms, there are reasons to suspect that the effects are even larger than our estimates suggest and have grown over time. Stock options might allow CEOs to capture an even larger part of the rents generated by a firm and the prevalence of options in CEO pay packages has increased tremendously since our sample period. In addtion, since we cannot control for rents directly, the estimates for CEOs are likely biased towards finding too small an impact of unions.

Apart from corroborating previous findings of cream skimming by CEOs, our results paint a broader view of the impact of unions in the workplace. The overwhelming part of the 
literature has focused on union impacts on those covered by collective bargaining or on nonunion workers through "threat effects" (employer fear of unionization inducing higher wages for their non-union employees) or "spillover effects" (lower non-union wages as a results of monopoly union employment effects). Our work, as Acemoglu and Newman (1997), stresses that unions might change the entire corporate structure of a unionized enterprise, and will therefore affect everyone in the firm. In fact, our results on the employment effects of managers and related occupations are among the strongest and most robust findings of this paper. These results might help explain the "productivity puzzle" in the union literature: the fact that unions seem to affect investment and growth of organized firms adversely without directly hurting productivity. According to the model, managers are not directly productive and higher wages are a substitute for the monitoring done by management. Unions therefore allow firms to produce more output per employee, even if that would not be the profit maximizing choice of the firm.

This broader role of unions also has a bearing on the role unions play for changes in wage inequality. While we are not able to quantify the magnitude of this effect, our evidence suggests that extant work on the determinants of wage inequality may systematically underestimate the role of declining unionization. The accounting exercises in DiNardo et al. (1996) and Bell and Pitt (1998), for example, assume that the role of unions in reducing inequality between groups is limited to the extent that unions raise the wages of union workers whose wages would otherwise be low in the absence of unionization. Specifically, both ignore the possible effects of unionization on the upper tail of the distribution. Indeed, such exercises would also be much more difficult to carry out if unions have indirect effects on groups like managers and executives; it is typically assumed that non-union workers form a comparison group from which we can extrapolate to covered workers when unionization rates fall over time. This exercise will fail, however, if the wages of the "comparison group" are themselves influenced by unionization.

We should emphasize, of course, that we have interpreted all our results through the 
lens of a particular model. Although we believe that rent sharing and the monitoring role of management are likely to be important aspects of any model of the impact of unions on the mangerial labor market, our data are not sufficiently rich to rule out some alternative explanations for our findings. For example, another way to rationalize our findings on the relationship between unionization and managerial wages would be to focus on wage inequality within firms and the unionization decision of workers. ${ }^{12}$ Unions compress wage inequality within firms. Consequently, workers below the median have an incentive to join a union. But if unions provide additional benefits such as redistributing rents to workers, some workers above the median will also have an incentive to join. Therefore, more workers will join the more equal the wage distribution in the firm is ex-ante, i.e. the less the most productive workers (among them managers) in the firm are paid. Alternatively, one could choose to focus on "fairness" or equity considerations by the union membership (Akerlof and Yellen 1990, Schlicht 1992) which would suggest that the "cost" of paying a manager or CEO a high wage may also include the cost of less effort on the part of union members. At a minimum, such models suggest interesting possible alternatives to explore.

\footnotetext{
${ }^{12}$ We thank a referee for suggesting this possibility.
} 


\section{Appendix 1: States and Industries Used in the CPS Analysis}

For the analysis in section 3 using CPS data we have grouped states and two digit industries into larger aggregates based on size and proximity, in order to assure that more of the cells we are using actually contain any observations.

The 16 regional aggregates are:

1. Maine, New Hampshire, Vermont, Massachusetts, Rhode Island

2. Connecticut, New York

3. New Jersey, Pennsylvania

4. Michigan, Ohio

5. Indiana, Illinois

6. Wisconsin, Minnesota, Iowa

7. Missouri, North Dakota, South Dakota, Nebraska, Kansas

8. Delaware, Maryland, Virginia, DC

9. West Virginia, North Carolina, South Carolina, Kentucky, Tennessee

10. Georgia, Florida

11. Alabama, Mississippi, Arkansas, Louisiana

12. Oklahoma, Texas

13. Idaho, Wyoming, Montana, Washington, Oregon

14. Colorado, New Mexico, Utah, Arizona, Nevada

15. California

16. Alaska, Hawaii

The 26 industry aggregates are (the CPS Detailed Industry Recodes are in parentheses):

1. Agriculture service, other agriculture, forestry and fisheries $(01-02,46)$

2. Mining (03) 
3. Construction (04)

4. Lumber, wood, furniture, fixtures, stone, clay, glass, and concrete (05-07)

5. Primary and fabricated metals, metals industries not specified (08-10)

6. Machinery, including electric, professional and photographic equipment, watches (11$12,16)$

7. Auto vehicles, aircraft, parts, and other transportation equipment (13-15)

8. Toys, amusement, and sporting goods, and miscellaneous manufacturing (17-18)

9. Food, tobacco, and kindred products (19-20)

10. Textiles, apparel, and leather products $(21-22,28)$

11. Paper, printing, publishing, and allied industries (23-24)

12. Chemicals, petroleum and coal products, rubber, miscellaneous plastic, and allied products $(25-27)$

13. Transportation (29)

14. Communications (30)

15. Utilities and sanitary services (31)

16. Wholesale trade (32)

17. Retail trade (33)

18. Banking and other finance (34)

19. Insurance and real estate (35)

20. Private household and personal services $(36,39)$

21. Business and other professional services $(37,45)$

22. Repair services (38)

23. Entertainment and recreation services (40)

24. Hospitals and health services (41-42)

25. Education services (43)

26. Social services (44) 


\section{Appendix 2: Construction of the International Data Sets}

The data for the fraction managers are taken from Table $2 \mathrm{C}$ of the ILO Yearbook of Labor Statistics, available on the internet at http://laborsta.ilo.org. We only used years in which employment by occupation was reported according the ISCO-68 classification and divided employment in occupation 2 (administrative and managerial) by total employment. We excluded three countries from the analysis because the ILO tables had unexplained breaks in the relevant series (Australia in 1986, Belgium in 1989, and Portugal in 1992).

We used the variable net union membership divided by the dependent labor force from the Trade Union Membership Database by Visser (1997). In order to impute this variable for country-year observations where net union membership was not available, we regressed the total union membership rate on the net membership rate within the part of our final sample where both measures are available. The imputed values are the predicted values from this regression. Other methods, e.g. simply using the total membership rate when the net rate is unavailable yielded very similar results.

The coverage rates are taken from Table 5.8 in OECD (1994) and Table 3.4 in OECD (1997). For the analysis in Table VI, we linearly interpolated the coverage rates for Denmark in 1993 (69), the Netherlands in 1981 (76), Spain in 1993 (77.5) and Switzerland in 1991 (52.25). For the regressions in Table VII, most values of the coverage rate had to be interpolated. We believe that this is rather accurate, however, since typically one value of coverage was available before 1984, between 1984 and 1988, as well as after 1992. Where interpolation was not possible, we dropped the corresponding observation, so that this sample for the pay regressions has only 69 observations, compared to 81 observations in the sample using union membership rates.

\section{References}

Abowd, John M., "The Effect of Wage Bargains on the Stock Market Value of the Firm," American Economic Review, September 1989, 79, 774-800.

and Michael L. Bognanno, "International Differences in Executive and Managerial Compensation," in Richard B. Freeman and Lawrence F. Katz, eds., Differences and Changes in Wage Structures, Chicago: The University of Chicago Press, 1995, pp. 67103.

Acemoglu, Daron and Andrew F. Newman, "The Labor Market and Corporate Structure," CEPR Working Paper 1708, Centre for Economic Policy Research October 1997. 
Akerlof, George and Janet Yellen, "The Fair Wage-Effort Hypothesis and Unemployment," Quarterly Journal of Economics, May 1990, 105 (2), 255-283.

Allen, Steven G., "Unionized Construction Workers are More Productive," Quarterly Journal of Economics, May 1984, 99 (2), 251-174.

Angrist, Joshua and Alan B. Krueger, "Empirical Strategies in Labor Economics," in Orley Ashenfelter and David Card, eds., Handbook of Labor Economics, Vol. 3, Amsterdam: North Holland, 1999.

Bell, Brian D. and Michael K. Pitt, "Trade Union Decline and The Distribution of Wages in the U.K.: Evidence from Kernel Density Estimation," Oxford Bulletin of Economics and Statistics, November 1998, 60 (4), 509-528.

Bertrand, Marianne and Sendhil Mullainathan, "Do CEO's Set Their Own Pay?: The Ones Without Principals Do," Unpublished Manuscript, Princeton University and MIT January 2000.

Blanchflower, David G., Neil Millward, and Andrew J. Oswald, "Unionism and Employment Behavior," Economic Journal, July 1991, 101 (407), 815-834.

Bok, Derek, The Cost of Talent. How Executives and Professionals are Paid and How It Affects America, New York: The Free Press, 1993.

Bronars, Stephen G., Donald R. Deere, and Joseph S. Tracy, "The Effect of Unions on Firm Behavior: An Empirical Analysis Using Firm Level Data," Industrial Relations, 1994, 33, 426-451.

Card, David, "The Effect of Unions on the Distribution of Wages: Redistribution or Relabelling?," NBER Working Paper 4195, National Bureau of Economic Research, Cambridge, MA. October 1992.

_ _ "The Effect of Unions on the Structure of Wages: A Longitudinal Analysis," Econometrica, 1996, 64, 957-979.

Clark, Kim B., "Unionization and Firm Performance: The Impact on Profits, Growth, and Productivity," American Economic Review, December 1984, 74 (5), 893-919.

Conyon, Martin, Paul Gregg, and Stephen Machin, "Taking Care of Business: Executive Compensation in the United Kingdom," Economic Journal, May 1995, 105, 704-714.

Crystal, Graef, In Search of Excess. The Overcompensation of the American Executive, Revised ed., New York: Norton, 1992. 
DeAngelo, Harry and Linda DeAngelo, "Union Negotiations and Corporate Policy. A Study of Labor Concessions in the Domestic Steel Industry During the 1980s," Journal of Financial Economics, 1991, 30, 3-43.

Dickens, William T. and Lawrence F. Katz, "Inter-Industry Wage Differences and Industry Characteristics," in Kevin Lang and Jonathan S. Leonard, eds., Unemployment and the Structure of Labor Markets, New York and Oxford: Blackwell, 1987, pp. 48-89.

DiNardo, John and Thomas Lemieux, "Diverging Male Wage Inequality in the United States and Canada, 1981-1988: Do Institutions Explain the Difference?," Industrial and Labor Relations Review, August 1997.

, Kevin Hallock, and Jörn-Steffen Pischke, "Unions and Managerial Pay," NBER Working Paper 5607, National Bureau of Economic Research, Cambridge, MA June 1997.

, Nicole Fortin, and Thomas Lemieux, "Labor Market Institutions and The Distribution of Wages, 1973-1993: A Semi-Parametric Approach," Econometrica, September 1996, 64 (5), 1001-1045.

Freeman, Richard B., "How Much Has De-Unionization Contributed to the Rise in Male Earnings Inequality?," in Sheldon Danziger and Peter Gottschalk, eds., Uneven Tides: Rising Inequality in America, New York: Russell Sage Foundation, 1993.

__ , "Labour Market Institutions and Earnings Inequality," New England Economic Review, May/June 1996, pp. 157-168.

and James L. Medoff, What Do Unions Do?, New York: Basic Books, 1984.

Gregg, Paul, Stephen Machin, and Stefan Szymanski, "The Disappearing Relationship Between Directors' Pay and Corporate Performance," British Journal of Industrial Relations, May 1993, 31, 1-10.

Hall, Brian J. and Jeffrey B. Liebman, "Are CEOs Really Paid Like Bureaucrats?, Quarterly Journal of Economics, August 1998, 113, 653-691.

Hallock, Kevin F., "Reciprocally Interlocking Boards of Directors and Executive Compensation," Journal of Financial and Quantitative Analysis, Septmeber 1997, 32 (3), $331-344$.

Hirsch, Barry T., Labor Unions and the Economic Performance of Firms, Kalamazoo: W.E. Upjohn Institute for Employment Research, 1991. 
Jensen, Michael C. and Kevin J. Murphy, "Performance Pay and Top-Management Incentives," Journal of Political Economy, 1990, 98, 225-264.

and William H. Meckling, "Theory of the Firm: Managerial Behavior, Agency Cost, and Ownership Structure," Journal of Financial Economics, October 1976, 3 (4), 305-360.

Joskow, Paul L., Nancy L. Rose, and Andrea Shepard, "Regulatory Constraints on CEO Compensation," Brookings Papers on Economic Activity: Microeconomics, 1993, 1, 1-58.

__ _ _ and Catherine D. Wolfram, "Political Constraints on CEO Compensation: Evidence from the Electric Utility Industry," Rand Journal of Economics, Spring 1996, $27(1), 165-182$.

Katz, Lawrence F. and Lawrence H. Summers, "Industry Rents: Evidence and Implications," Brookings Papers on Economic Activity, 1989, pp. 209-275.

Machin, Stephen and Sushil Wadhwani, "The Effects of Unions on Organisational Change and Employment," Economic Journal, July 1991, 101 (407), 835-854.

Murphy, Kevin J., "Executive Compensation," in Orley Ashenfelter and David Card, eds., Handbook of Labor Economics, Vol. 3B, North-Holland, 1999, chapter 38, pp. 2485-2563.

Neumark, David and Michael L. Wachter, "Union Effects on Nonunion Wages: Evidence from Panel Data on Industries and Cities," Industrial and Labor Relations Review, 1995, 49, 20-38.

OECD, "Collective Bargaining: Levels and Coverage," OECD Employment Outlook, 1994, pp. 167-194.

__ , "Economic Performance and the Structure of Collective Bargaining," OECD Employment Outlook, 1997, pp. 63-92.

Schlicht, Ekkehart, "Wage Generosity," Journal of Institutional and Theoretical Economics, September 1992, 148 (3), 437-451.

Visser, Jelle, "Trade Union Membership Database," Unpublished Dataset, Amsterdam 1997. 
Table I:

Industry/State Level Data from the CPS

Weighted Cell Means

\begin{tabular}{|c|c|c|c|c|}
\hline \multirow[t]{2}{*}{ Occupation } & \multirow[t]{2}{*}{ Managers } & \multirow{2}{*}{$\begin{array}{l}\text { Management } \\
\text { Related }\end{array}$} & \multicolumn{2}{|c|}{ Workers } \\
\hline & & & Non-Union & Union \\
\hline & \multicolumn{4}{|c|}{1983} \\
\hline Log Hourly Wage & 2.32 & 2.27 & 1.71 & 2.15 \\
\hline Years of School & 14.4 & 14.8 & 12.3 & 11.8 \\
\hline Potential Experience & 20.8 & 17.7 & 17.2 & 22.3 \\
\hline Female & .324 & .438 & .509 & .273 \\
\hline Black & .032 & .042 & .080 & 119 \\
\hline Fraction Unionized in Occ. & 059 & .056 & .000 & 1.000 \\
\hline Fraction Union Workers & 188 & 171 & 160 & .368 \\
\hline \multirow[t]{2}{*}{ Fraction Managers } & .081 & .081 & .064 & .061 \\
\hline & \multicolumn{4}{|c|}{1993} \\
\hline Log Hourly Wage & 2.67 & 2.63 & 2.10 & 2.47 \\
\hline Years of School & 14.4 & 14.6 & 12.4 & 12.2 \\
\hline Potential Experience & 20.8 & 18.3 & 18.5 & 23.4 \\
\hline Female & .414 & .576 & .501 & .286 \\
\hline Black & .043 & .058 & 090 & .132 \\
\hline Fraction Unionized in Occ. & .038 & .035 & .000 & 1.000 \\
\hline Fraction Union Workers & 130 & 107 & 115 & .272 \\
\hline Fraction Managers & .097 & .107 & .078 & .078 \\
\hline
\end{tabular}

Data source: Current Population Survey Merged Outgoing Rotation Groups from 1983 to 1993. Means of state/industry cells. Means are weighted by the number of observations in the cells. 
Table II:

The Effect of Unions on the Fraction Managers in an Industry Regressions on Industry/State/Year Level Data from the CPS

\begin{tabular}{|c|c|c|c|c|c|c|}
\hline Independent Variable & $(1)$ & $(2)$ & $(3)$ & $(4)$ & $(5)$ & $(6)$ \\
\hline \multicolumn{7}{|c|}{ Dependent Variable: Fraction Managers } \\
\hline Fraction of Workers Unionized & $\begin{array}{l}-.082 \\
(.006)\end{array}$ & $\begin{array}{l}-.074 \\
(.006)\end{array}$ & $\begin{array}{l}-.033 \\
(.004)\end{array}$ & $\begin{array}{l}-.095 \\
(.006)\end{array}$ & $\begin{array}{l}-.088 \\
(.006)\end{array}$ & $\begin{array}{c}-.036 \\
(.004)\end{array}$ \\
\hline Union Wage Differential & - & $\begin{array}{l}-.038 \\
(.004)\end{array}$ & $\begin{array}{l}-.011 \\
(.003)\end{array}$ & - & $\begin{array}{l}-.024 \\
(.004)\end{array}$ & $\begin{array}{l}-.009 \\
(.003)\end{array}$ \\
\hline Industry Wage Differential & - & - & - & $\begin{array}{c}.007 \\
(.005)\end{array}$ & $\begin{array}{c}.068 \\
(.005)\end{array}$ & $\begin{array}{c}.013 \\
(.006)\end{array}$ \\
\hline \multicolumn{7}{|c|}{ Dependent Variable: Fraction Managers and Related Occupations } \\
\hline Fraction of Workers Unionized & $\begin{array}{l}-.128 \\
(.010)\end{array}$ & $\begin{array}{l}-.111 \\
(.010)\end{array}$ & $\begin{array}{l}-.041 \\
(.005)\end{array}$ & $\begin{array}{l}-.163 \\
(.009)\end{array}$ & $\begin{array}{l}-.152 \\
(.009)\end{array}$ & $\begin{array}{l}-.049 \\
(.005)\end{array}$ \\
\hline Union Wage Differential & - & $\begin{array}{l}-.083 \\
(.006)\end{array}$ & $\begin{array}{l}-.017 \\
(.003)\end{array}$ & - & $\begin{array}{l}-.042 \\
(.006)\end{array}$ & $\begin{array}{c}-.012 \\
(.003)\end{array}$ \\
\hline Industry Wage Differential & - & - & - & $\begin{array}{c}.216 \\
(.008)\end{array}$ & $\begin{array}{c}.201 \\
(.008)\end{array}$ & $\begin{array}{c}.039 \\
(.007)\end{array}$ \\
\hline Ind & Yes & Yes & Yes & Yes & Yes & Yes \\
\hline Industry*Year Effects & No & No & Yes & No & No & Yes \\
\hline
\end{tabular}

Data source: Current Population Survey Merged Outgoing Rotation Groups from 1983 to 1993. The number of observations is 4,502. The dependent variable is the fraction of managers or managers and related occupations in a state/industry/year cell. The union wage differential is obtained from a similar regression for union and non-union workers which also included a full set of state/industry/year/union interactions. It is obtained by subtracting the union coefficient from the non-union coefficient for the cell. The industry (state/year) wage differential is the the set of coefficients for non-union workers from the same regression. Regressions are weighted by the number of observations in the cells. Standard errors are in parentheses. 
Table III:

The Effect of Unions on Manager Wages Regressions on Industry/State/Year Level Data from the CPS

\begin{tabular}{|c|c|c|c|c|c|c|}
\hline Independent Variable & $(1)$ & $(2)$ & $(3)$ & $(4)$ & $(5)$ & $(6)$ \\
\hline \multicolumn{7}{|c|}{ Dependent Variable $\ln$ (Wage of Managers) } \\
\hline \multirow[t]{2}{*}{ Fraction of Workers Unionized } & 0.021 & 0.021 & 0.076 & -0.051 & -0.058 & 0.008 \\
\hline & $(0.024)$ & $(0.024)$ & $(0.022)$ & $(0.021)$ & $(0.022)$ & $(0.022)$ \\
\hline \multirow[t]{2}{*}{ Fraction of Managers Unionized } & & 0.005 & 0.040 & & 0.050 & 0.063 \\
\hline & & $(0.037)$ & $(0.033)$ & & $(0.033)$ & $(0.032)$ \\
\hline \multirow[t]{2}{*}{ Industry Wage Differential } & & & & 0.543 & 0.544 & 0.435 \\
\hline & & & & $(0.017)$ & $(0.017)$ & $(0.026)$ \\
\hline \multicolumn{7}{|c|}{ Dependent Variable: $\ln$ (Wage of Management Related Occupations) } \\
\hline \multirow[t]{2}{*}{ Fraction of Workers Unionized } & -0.043 & -0.041 & 0.084 & -0.072 & -0.074 & 0.022 \\
\hline & $(0.030)$ & $(0.030)$ & $(0.030)$ & $(0.028)$ & $(0.028)$ & $(0.030)$ \\
\hline Fraction of Management & & -0.008 & -0.001 & & 0.012 & 0.005 \\
\hline Related Occs Unionized & & $(0.028)$ & $(0.027)$ & & $(0.026)$ & $(0.026)$ \\
\hline \multirow[t]{2}{*}{ Industry Wage Differential } & & & & 0.601 & 0.601 & 0.444 \\
\hline & & & & $(0.023)$ & $(0.023)$ & $(0.034)$ \\
\hline Industry, Region, Year Effects & Yes & Yes & Yes & Yes & Yes & Yes \\
\hline Industry*Year Effects & No & No & Yes & No & No & Yes \\
\hline
\end{tabular}

Data source: Current Population Survey Merged Outgoing Rotation Groups from 1983 to 1993. The number of observations is 4123 for managers and 4426 for management related occupations. The industry (state/year) wage differential is the the set of coefficients for non-union workers from the same regression. Regressions are weighted by the number of observations in the cells. Standard errors are in parentheses. 
Table IV:

The Effect of Unions on CEO Pay

Dependent Variable: Ln(Salary, Bonus and Other CEO Compensation)

Firm Level Regressions Using Bronars, Deere, and Tracy Data

\begin{tabular}{lccccccc}
\hline \hline & $\begin{array}{c}\text { Mean } \\
\text { (Std. Dev. })\end{array}$ & Full & Manuf. & Non-Manuf. & Full & Full & Full \\
Independent & & & & & & \\
Variable & & $(1)$ & $(2)$ & $(3)$ & $(4)$ & $(5)$ & $(6)$ \\
\hline Fraction Union & 0.319 & -0.303 & -0.186 & -0.185 & -0.120 & 0.015 & 0.252 \\
& $(0.246)$ & $(0.054)$ & $(0.061)$ & $(0.095)$ & $(0.054)$ & $(0.058)$ & $(0.107)$ \\
CEO Age & 57.61 & 0.019 & 0.040 & -0.048 & -0.009 & -0.007 & -0.010 \\
& $(5.872)$ & $(0.023)$ & $(0.023)$ & $(0.061)$ & $(0.023)$ & $(0.024)$ & $(0.031)$ \\
CEO Age ${ }^{2} / 100$ & 33.53 & -0.015 & -0.034 & 0.049 & 0.010 & 0.007 & 0.015 \\
& $(6.769)$ & $(0.021)$ & $(0.020)$ & $(0.053)$ & $(0.020)$ & $(0.021)$ & $(0.027)$ \\
CEO Tenure & 7.655 & 0.018 & 0.021 & 0.023 & 0.016 & 0.020 & 0.020 \\
& $(5.975)$ & $(0.006)$ & $(0.007)$ & $(0.010)$ & $(0.005)$ & $(0.005)$ & $(0.006)$ \\
CEO Tenure & 0.943 & -0.032 & -0.068 & -0.015 & -0.036 & -0.053 & -0.043 \\
& $(1.752)$ & $(0.020)$ & $(0.027)$ & $(0.032)$ & $(0.019)$ & $(0.018)$ & $(0.019)$ \\
New CEO & 0.246 & -0.064 & -0.047 & -0.107 & -0.057 & -0.065 & -0.059 \\
& $(0.431)$ & $(0.030)$ & $(0.031)$ & $(0.062)$ & $(0.026)$ & $(0.025)$ & $(0.021)$ \\
Log Sales & 7.885 & 0.148 & 0.230 & 0.153 & 0.236 & 0.187 & -0.023 \\
& $(1.000)$ & $(0.026)$ & $(0.026)$ & $(0.066)$ & $(0.040)$ & $(0.047)$ & $(0.080)$ \\
Log Employment & 3.185 & 0.176 & 0.035 & 0.190 & 0.043 & 0.090 & 0.362 \\
& $(1.025)$ & $(0.025)$ & $(0.028)$ & $(0.056)$ & $(0.040)$ & $(0.047)$ & $(0.078)$ \\
Stock Return & 0.127 & 0.070 & 0.064 & 0.101 & 0.067 & 0.068 & 0.065 \\
& $(0.871)$ & $(0.016)$ & $(0.016)$ & $(0.038)$ & $(0.014)$ & $(0.014)$ & $(0.014)$ \\
Stock Return & 0.270 & 0.017 & 0.020 & 0.003 & 0.018 & 0.023 & 0.017 \\
last period & $(1.505)$ & $(0.009)$ & $(0.011)$ & $(0.015)$ & $(0.009)$ & $(0.008)$ & $(0.011)$ \\
Period (1974-1978) & 0.332 & 0.322 & 0.360 & 0.197 & 0.319 & 0.330 & 0.336 \\
& $(0.471)$ & $(0.035)$ & $(0.035)$ & $(0.077)$ & $(0.030)$ & $(0.028)$ & $(0.025)$ \\
Period (1974-1978) & 0.299 & 0.738 & 0.787 & 0.616 & 0.747 & 0.759 & 0.775 \\
& $(0.458)$ & $(0.033)$ & $(0.033)$ & $(0.073)$ & $(0.029)$ & $(0.027)$ & $(0.027)$ \\
\hline Number of Observations & 782 & 782 & 577 & 205 & 782 & 782 & 782 \\
\hline Industry Effects & & No & No & No & 44 & 103 & No \\
Firm Effects & & No & No & No & No & No & 327 \\
\hline \hline
\end{tabular}

Data sources: Unionization rates are from Bronars, Deere, and Tracy (1994), CEO pay data are from Kevin Murphy, all other variables are from Compustat. Data refer to four year aggregates for 1971-74, 1975-78, and 1979-82. Standard errors are in parentheses. 
Table V:

The Effect of Unions on CEO Pay

Dependent Variable: Ln(Salary, Bonus and Other CEO Compensation) Firm Level Regressions Using Hirsch Data

\begin{tabular}{lccccc}
\hline \hline Independent Variable & $\begin{array}{c}\text { Mean } \\
\text { (Std. Dev. })\end{array}$ & $(1)$ & $(2)^{*}$ & $(3)$ & $(4)$ \\
& 0.367 & -0.146 & -0.194 & -0.075 & -0.095 \\
Fraction Union & $(0.255)$ & $(0.078)$ & $(0.084)$ & $(0.090)$ & $(0.124)$ \\
CEO Age & 56.96 & 0.028 & -0.065 & 0.018 & 0.011 \\
& $(5.330)$ & $(0.054)$ & $(0.060)$ & $(0.059)$ & $(0.069)$ \\
CEO Age $/ 100$ & 32.72 & -0.014 & 0.062 & -0.006 & 0.000 \\
& $(5.998)$ & $(0.049)$ & $(0.053)$ & $(0.052)$ & $(0.062)$ \\
CEO Tenure & 7.538 & 0.000 & 0.020 & -0.007 & -0.007 \\
& $(5.945)$ & $(0.010)$ & $(0.011)$ & $(0.011)$ & $(0.013)$ \\
CEO Tenure ${ }^{2} / 100$ & 0.920 & -0.016 & -0.073 & 0.005 & -0.001 \\
& $(1.882)$ & $(0.031)$ & $(0.035)$ & $(0.035)$ & $(0.041)$ \\
New CEO & 0.198 & -0.123 & -0.128 & -0.101 & -0.072 \\
& $(0.400)$ & $(0.052)$ & $(0.050)$ & $(0.053)$ & $(0.064)$ \\
Log(Sales) & 7.756 & 0.172 & 0.139 & 0.005 & -0.049 \\
& $(1.030)$ & $(0.040)$ & $(0.038)$ & $(0.070)$ & $(0.103)$ \\
Log(employment) & 3.125 & 0.155 & 0.217 & 0.316 & 0.362 \\
& $(1.020)$ & $(0.040)$ & $(0.039)$ & $(0.065)$ & $(0.099)$ \\
Stock Return & 0.048 & 0.132 & 0.131 & 0.151 & 0.195 \\
& $(0.620)$ & $(0.035)$ & $(0.034)$ & $(0.038)$ & $(0.053)$ \\
Stock Return & 0.070 & 0.048 & 0.080 & 0.040 & 0.028 \\
last period & $(0.819)$ & $(0.027)$ & $(0.026)$ & $(0.029)$ & $(0.035)$ \\
\hline Number of Observations & 227 & 227 & 196 & 227 & 227 \\
\hline Industry Effects & No & No & No & 30 & 85 \\
\hline \hline
\end{tabular}

Data sources: Unionization rates are from Hirsch (1991), CEO pay data are from Kevin Murphy, all other variables are from Compustat. All variables except unionization rates are aggregates for the four years 1975-1978. Standard errors are in parentheses. Unionization rates refer to 1977.

* Only firms with positive unionization rates. 
Table VI:

The Effect of Unions on the Fraction Managers Across Countries

Dependent Variable: Fraction Managers Cross Country Panel Regressions

\begin{tabular}{|c|c|c|c|c|}
\hline Independent Variable & $\overline{\text { Full }}$ & $\overline{\text { Full }}$ & $\overline{\text { Full }}$ & $\begin{array}{c}\text { Canada } \\
\text { Excluded } \\
(4)\end{array}$ \\
\hline Union Membership Rate & $\begin{array}{l}-.052 \\
(.047)\end{array}$ & $\begin{array}{l}-.049 \\
(.050)\end{array}$ & $\begin{array}{c}.037 \\
(.050)\end{array}$ & $\begin{array}{c}.000 \\
(.026)\end{array}$ \\
\hline Number of Observations & 189 & 189 & 189 & 168 \\
\hline Union Coverage Rate & $\begin{array}{c}-.088 \\
(.042)\end{array}$ & $\begin{array}{l}-.100 \\
(.036)\end{array}$ & $\begin{array}{l}-.023 \\
(.068)\end{array}$ & $\begin{array}{l}-.020 \\
(.072)\end{array}$ \\
\hline Number of Observations & 28 & 28 & 28 & 25 \\
\hline Time Dummies & No & Yes & Yes & Yes \\
\hline Country Dummies & No & No & Yes & Yes \\
\hline
\end{tabular}

Data sources: Data on Managerial Employment are from ILO. Unionization rates are from Visser (1997) with assistance from Danny Blanchflower and Michael Wallerstein. Coverage rates are from OECD (1994) and OECD (1997). Data refer to 16 countries for the membership data and 11 countries for the coverage data and cover the years 1970 to 1993. Standard errors in parentheses are adjusted for grouping by country. 
Table VII:

The Effect of Unions on CEO Pay Across Countries Cross Country Panel Regressions

\begin{tabular}{|c|c|c|c|c|c|c|c|c|}
\hline Independent Variabel & $(1)$ & $(2)$ & $(3)$ & $(4)$ & $(5)$ & $(6)$ & $(7)$ & (8) \\
\hline & \multicolumn{8}{|c|}{ Dependent Variable: } \\
\hline & \multicolumn{4}{|c|}{ Ln(Real Total Compensation) } & \multicolumn{4}{|c|}{ Ln(PPP Total Compensation) } \\
\hline \multirow[t]{2}{*}{ Union Membership Rate } & -.530 & -.293 & -.229 & .385 & -1.019 & -.729 & -.451 & .185 \\
\hline & $(.257)$ & $(.164)$ & $(.152)$ & $(1.602)$ & $(.304)$ & $(.180)$ & $(.236)$ & $(.777)$ \\
\hline Time Trend & - & - & $\begin{array}{l}.101 \\
(.015)\end{array}$ & - & - & - & $\begin{array}{l}.054 \\
(.007)\end{array}$ & - \\
\hline US Dummy & - & $\begin{array}{l}.819 \\
(.078)\end{array}$ & $\begin{array}{l}.786 \\
(.060)\end{array}$ & - & - & $\begin{array}{l}.580 \\
(.055)\end{array}$ & $\begin{array}{l}.494 \\
(.057)\end{array}$ & - \\
\hline US Incremental Trend & - & $\begin{array}{l}-.046 \\
(.009)\end{array}$ & $\begin{array}{l}-.044 \\
(.007)\end{array}$ & - & - & $\begin{array}{l}.022 \\
(.007)\end{array}$ & $\begin{array}{l}.020 \\
(.007)\end{array}$ & - \\
\hline \multirow{5}{*}{$\begin{array}{l}\text { Marginal Employee } \\
\text { Tax Rate } \\
\text { Marginal Corporate } \\
\text { Tax Rate }\end{array}$} & - & - & -.147 & - & - & - & $\begin{array}{l}-.602 \\
(227)\end{array}$ & - \\
\hline & - & - & $\begin{array}{l}(.100) \\
.245\end{array}$ & - & - & - & $\begin{array}{c}(.231) \\
.220\end{array}$ & - \\
\hline & & & $(.315)$ & & & & $(.382)$ & \\
\hline & & & & ependent & Variable & & & \\
\hline & $\operatorname{Ln}(\operatorname{Re}$ & al Total & Compes & sation) & $\operatorname{Ln}(\mathrm{PPI}$ & Total & Compen & sation) \\
\hline Union Coverage Rate & -.482 & -.125 & -.075 & -.605 & -.636 & -.175 & .023 & -.248 \\
\hline \multirow{2}{*}{ Time Trend } & $\stackrel{(.277)}{-}$ & $(.093)$ & $\begin{array}{c}(.079) \\
.096\end{array}$ & $(.706)$ & $\stackrel{(.407)}{-}$ & $\stackrel{(.238)}{-}$ & $\begin{array}{c}(.163) \\
.030\end{array}$ & $\stackrel{(.535)}{-}$ \\
\hline & & & $(.012)$ & & & & $(.014)$ & \\
\hline \multirow[t]{2}{*}{ US Dummy } & - & .778 & .783 & - & - & .479 & .481 & - \\
\hline & & $(.060)$ & $(.053)$ & & & $(.153)$ & $(.094)$ & \\
\hline US Incremental Trend & - & $\begin{array}{l}-.042 \\
(.008)\end{array}$ & $\begin{array}{l}-.044 \\
(.008)\end{array}$ & - & - & $\begin{array}{l}.043 \\
(.011)\end{array}$ & $\begin{array}{l}.031 \\
(.008)\end{array}$ & - \\
\hline \multirow{2}{*}{$\begin{array}{l}\text { Marginal Employee } \\
\text { Tax Rate }\end{array}$} & - & - & -.155 & - & - & - & -.754 & - \\
\hline & & & $(.161)$ & & & & $(.306)$ & \\
\hline \multirow{2}{*}{$\begin{array}{l}\text { Marginal Corporate } \\
\text { Tax Rate }\end{array}$} & - & - & .361 & - & - & - & .114 & - \\
\hline & & & $(.261)$ & & & & $(.500)$ & \\
\hline \multirow{2}{*}{$\begin{array}{l}\text { Time Dummies } \\
\text { Country Dummies }\end{array}$} & Yes & Yes & No & Yes & Yes & Yes & No & Yes \\
\hline & No & No & No & Yes & No & No & No & Yes \\
\hline
\end{tabular}

Data sources: Data on CEO compensation are from Abowd and Bognanno (1995). Unionization rates are from Visser (1997) with assistance from Danny Blanchflower and Michael Wallerstein. Coverage rates are from OECD (1994) and OECD (1997). Data refer to 12 countries and the periods 1984, 1988-1992. Number of observations is 81 for the membership data and 69 for the coverage data. All regressions also include dummies for the data source. Multiple observations for a particular year and country may be available from different sources. Standard errors in parentheses are adjusted for grouping by country. 